\title{
Assessment of Physicochemical and Major Chemical Parameters of Spring Waters from Iddo Wara Wale Local Area, Oromia Region, Ethiopia
}

\author{
Habtamu Abdisa $^{1^{\star}}$ and Alemayehu Abebaw ${ }^{2}$ \\ ${ }^{1}$ Department of Chemistry, Mizan-Tepi University, Post Box No: 121, Tepi, SNNP Region, Ethiopia \\ ${ }^{2}$ Department of Chemistry, Ambo University, Post Box No: 19, Ambo, Oromia Region, Ethiopia
}

\begin{abstract}
The study was undertaken to assess the physicochemical and major chemical parameters of water springs in Iddo Wara Wale area of Dale Sadi district of Kellem Wollega, Oromia, Ethiopia. A total of $20 \mathrm{~L}$ samples were collected from five densely populated springs, namely: Ittisa, Abba Moga, Kersa, Ele Gonda and Merfata during drying season. All samples were analyzed for seven physicochemical parameters: temperature, $\mathrm{pH}$, conductivity, total dissolved solids, chemical oxygen demand, alkalinity and total hardness, and for eight major chemical parameters $\left(\mathrm{SO}_{4}{ }^{2-}, \mathrm{PO}_{4}{ }^{3-}, \mathrm{NO}_{3}{ }^{-}, \mathrm{Cl}^{-}, \mathrm{Ca}, \mathrm{Mg}, \mathrm{Na}\right.$ and $\left.\mathrm{K}\right)$ according to standard methods. Temperature, $\mathrm{pH}$ and conductivity were measured in-situ. The chemical oxygen demand, alkalinity, total hardness, $\mathrm{SO}_{4}{ }^{2-}, \mathrm{Cl}^{-}, \mathrm{Ca}$ and $\mathrm{Mg}$ were determined by titrimetric methods. $\mathrm{PO}_{4}{ }^{3-}$ and $\mathrm{NO}_{3}{ }^{-}$were determined by validated UV-Vis Spectrophotometry while $\mathrm{Na}$ and $\mathrm{K}$ were analyzed by validated Flame Photometry. The mean values of temperature, $\mathrm{pH}$, and conductivity were ranged from 19.78 to $21.85^{\circ} \mathrm{C}, 6.67$ to 7.44 , and 22.1 to $47.1 \mu \mathrm{S} / \mathrm{cm}$, respectively. The results for total dissolved solids, chemical oxygen demand, alkalinity, and total hardness were ranged from 17.8 to 32.9 $\mathrm{mg} / \mathrm{L}, 5.12$ to $8.06 \mathrm{mg} / \mathrm{L}, 5.76$ to $7.56 \mathrm{mg} / \mathrm{L}$, and 18.0 to $27.6 \mathrm{mg} / \mathrm{L}$, respectively. For major chemical analyses mean values were ranged from 1.74 to $2.53 \mathrm{mg} / \mathrm{L}$ for $\mathrm{SO}_{4}{ }^{2-}, 0.21$ to $0.31 \mathrm{mg} / \mathrm{L}$ for $\mathrm{PO}_{4}{ }^{3-}, 0.62$ to $0.87 \mathrm{mg} / \mathrm{L}$ for $\mathrm{NO}_{3}{ }^{-}, 3.1$ to $5.3 \mathrm{mg} / \mathrm{L}_{\text {for }} \mathrm{Cl}^{-}, 4.49$ to $7.37 \mathrm{mg} / \mathrm{L}$ for $\mathrm{Ca}, 1.45$ to 2.23 for $\mathrm{Mg}, 1.12$ to $1.58 \mathrm{mg} / \mathrm{L}$ for $\mathrm{Na}$ and 0.61 to $0.81 \mathrm{mg} / \mathrm{L}$ for $\mathrm{K}$. All analyzed parameters were below WHO and Ethiopian guidelines for drinking water quality. The results showed that the waters were unpolluted and can fit for human consumption. However, for further improvement analyses of the remaining water quality indicators were recommended.
\end{abstract}

Article Information

Copyright@2014 STAR Journal. All Rights Reserved.

Article History:

Received : 15-02-2014

Revised : 08-06-2014

Accepted : 13-06-2014 Keywords:

Flame Photometry

Iddo Wara Wale

major chemical

physicochemical

spring water

titrimetric methods

${ }^{*}$ Corresponding Author:

Habtamu Abdisa

E-mail:

habtishalem@yahoo.com abdiihabtish@gmail.com

\section{INTRODUCTION}

Water, always a vital commodity for humans, is used for drinking, cooking, agriculture, transport, and recreation, among other purposes (Namiesnik and Szefer, 2010). But most important is the fact that water is a major constituent of all living matter, comprising up to two-thirds of the human body. Next to air we breathe, water is mankind's most important substance (Lawson, 2011). Freshwater is a finite resource, essential for agriculture, industry and even human existence. Without freshwater of adequate quantity and quality sustainable development will not be possible (Ministry of water resources, 2008). In Ethiopia, the dominant source of drinking water used to supply major urban and rural communities is from wells and springs. Although there are no systematic and comprehensive water quality assessment programs in the country, there are increasing indications of water contamination problems in some parts of the country (Gebrekidan and Samuel, 2011). The major causes of this contamination could be soil erosion, domestic waste from urban and rural areas, agricultural activities, industrial wastes, inadequate treatment, and over-use of limited water resources (Onwughara et al., 2013; Gebrekidan and Samuel, 2011; Alley, 2007). The common water sources in Iddo Wara Wale area communities for drinking and other domestic uses is a naturally occurring springs. Many of these springs are road side springs which are susceptible to contamination from human and animal wastes. According to Tebbutt (1998), spring water is normally of good quality provided that it is derived from an aquifer and is not simply the discharge of a stream which has gone underground for a short distance. Therefore, it is important to maintain this good quality by protecting the spring and its surroundings from contamination by humans and animals.

Water has unique chemical properties due to its polarity and hydrogen bonds which means it is able to dissolve, absorb, adsorb or suspend many different compounds, thus, in nature, water is not pure as it acquires contaminants from its surrounding and those arising from humans and animals as well as other biological activities (WHO, 2007; McMurry and Fay, 2004). The international water community continues to highlight good water quality as vital for securing the future of human and aquatic ecosystem health (UNEP, 2004). Thus, it is needed to emphasize the quality of water in the area under study since the communities are using water of untested quality for drinking. 
Habtamu Abdisa and Alemayehu Abebaw

This study is particularly aimed to determine the physicochemical parameters including temperature, conductivity, total dissolved solids (TDS), chemical oxygen demand (COD), $\mathrm{pH}$, alkalinity and total hardness, and major chemical parameters including $\mathrm{Ca}, \mathrm{Mg}, \mathrm{Na}, \mathrm{K}$, $\mathrm{Cl}^{-}, \mathrm{NO}_{3}^{-}, \mathrm{PO}_{4}{ }^{3-}$ and $\mathrm{SO}_{4}{ }^{2-}$. It is also aimed to determine whether these parameters meet the WHO (World Health Organization) and Ethiopian standards for drinking water, as well as to find out the possible causes of any contaminations to make appropriate recommendations. The results of the study will also expected to give the baseline information for water quality study in Iddo Wara Wale local area in the future.

\section{MATERIALS AND METHODS}

\section{Study Area}

The study was took place in Iddo Wara Wale local area communities in Dale Sadi district, Kellem Wollega, western part of Oromia regional state, Ethiopia. Iddo Wara Wale area is situated at $18 \mathrm{Km}$ to the north from Haro Sabu town (853'59.12"N, 35¹3'28.28"E, elev $5015 \mathrm{ft}$, and eye alt $54.83 \mathrm{mi}$ ) of Dale Sadi Woreda. There are a total of twelve known water springs in this rural area: Ittisa, Mumme, Abba Busuna, Abba Moga, Kersa, Gombo, Okote, Malka Kiltu, Ele Gonda, Kofale, Kore and Merfata Spring with an estimated population of 5,525 people. To investigate the quality of drinking water in this area five springs (Ittisa, Abba Moga, Kersa, Ele Gonda and Merfata) were purposively considered. The purposive selections of spring sites are based on the number of consumers of the springs. The study area is a naturally gifted with different types of rocks (sedimentary rocks, metamorphic, and igneous rocks) which may contribute different mineral constituents to the water body.

\section{Sample Collection, Treatment and Transportation}

Representative water samples from sampling sites were collected into $1 \mathrm{~L}$-capacity polyethylene bottles in duplicates by grab sampling technique, using the same sampling protocol at all sites. From each spring sites six bottles of water samples were taken based on the types of parameters being determined and its pretreatment required: the $1^{\text {st }}$ two bottles were treated with $1.5 \mathrm{~mL}$ of conc. $\mathrm{HNO}_{3}$ to $\mathrm{pH}<2$ for potassium and sodium analyses, the $2^{\text {nd }}$ two bottles were treated with $1.5 \mathrm{~mL}$ of conc. $\mathrm{H}_{2} \mathrm{SO}_{4}$ to $\mathrm{pH}<2$ for $\mathrm{COD}$ and total phosphorous analyses, and the $3^{\text {rd }}$ two bottles were preserved for other parameters. The collected samples were stored in an icebox at a temperature of $4^{\circ} \mathrm{C}$ and transported to the Ambo University Chemistry laboratory for analysis.

\section{Physicochemical Analysis}

Physicochemical properties are parameters that do not identify particular chemical species but are used as indicators of how water quality may affect water uses (Weiner, 2008). Some of these parameters determined include temperature, $\mathrm{pH}$, conductivity, total dissolved solids, chemical oxygen demand, total hardness and alkalinity.

Temperature: The temperature was measured with a mercury thermometer $\left(0-100^{\circ} \mathrm{C}\right)$. Readings were made with the thermometer immersed in water long enough to permit complete equilibration.

pH: The $\mathrm{pH}$ was measured with a portable $\mathrm{pH}$-meter (ELMEIRON $^{\circledR}$ Zabrze-Grzybowice, POLAND). The $\mathrm{pH}$ -
Sci. Technol. Arts Res. J., April-June 2014, 3(2): 103-112

meter was calibrated with a buffer solution of $\mathrm{pH} 7.0$ according to the procedures given on the manufacturer's instruction manual. One buffer tablet was dissolved in a $100 \mathrm{~mL}$ volume of distilled water to prepare the buffer solution. The $\mathrm{pH}$-meter was calibrated before and after measurements prior to each site of sampling.

Conductivity: The conductivity was measured with a portable conductivity meter $\left(\right.$ ELMEIRON $^{\circledR}$ ZabrzeGrzybowice, CC-101, POLAND), following the procedures given in the manufacturer's instruction manual.

Total Dissolved Solids (TDS): TDS was measured with Conductivity/TDS/Salinity/Resistivity Meter (SCHOTTGERATE GmbH. Hattenbergstr.10, SX713, TDS working range: $0-100 \mathrm{~g} / \mathrm{L}$ ), as soon as the samples were transported to the laboratory. The device was calibrated with $0.01 \mathrm{M} \mathrm{KCl}$ solution following the procedures given in the manufacturer's instruction manual before the measurements were made.

Chemical Oxygen Demand (COD): The COD was determined by open reflux method following the procedures given in 'Section 5220 B.4b') of the standard methods (APHA, 1999).

Total Hardness: The total hardness was determined by EDTA titrimetric method given in 'Section $2340 \mathrm{C}$ ' of standard methods (APHA, 1999).

Alkalinity: The alkalinity was determined by titrimetric method following the procedure given in Handbook of Methods in Environmental Studies: Water and Wastewater Analysis (Maiti, 2004).

\section{Major Chemical Analysis}

Major chemical parameters are those most often present in natural waters in concentrations greater than $1.0 \mathrm{mg} / \mathrm{L}$ (Weiner, 2008). Some of the major chemical parameters determined include sulphate, chloride, calcium, magnesium, sodium, potassium, phosphate and nitrate.

Calcium (Ca): Ca was determined by EDTA Titrimetric Method given in 'Section 3500-Ca B') of standard methods (APHA, 1999).

Magnesium (Mg): $\mathrm{Mg}$ was determined by Calculation Method 'Section 3500-Mg B') of standard methods (APHA, 1999).

Sulphate $\left(\mathrm{SO}_{4}{ }^{2-}\right): \mathrm{SO}_{4}{ }^{2-}$ was determined by Gravimetric Method with Ignition of Residue given in 'Section 4500$\mathrm{SO}_{4}{ }^{2-} \mathrm{C}^{\prime}$ ) of standard methods.

Chloride $\left(\mathrm{Cl}^{-}\right)$: $\mathrm{Cl}^{-}$was determined by Argentometric Method given in 'Section 4500- $\mathrm{Cl}^{-} \mathrm{B}$ ' of standard methods (APHA, 1999).

Sodium (Na) and Potassium (K): $\mathrm{Na}$ and $\mathrm{K}$ were determined by flame photometric method following the instrument working conditions given in Table 1.

Phosphate $\left(\mathrm{PO}_{4}{ }^{3-}\right)$ and Nitrate $\left(\mathrm{NO}_{3}{ }^{-}\right): \mathrm{PO}_{4}{ }^{3-}$ and $\mathrm{NO}_{3}{ }^{-}$ were determined by UV-Vis Spectrophotometric method following the instrument working conditions given in Table 1. 
Table 1: Instruments operating conditions for calibration and sample analyses.

\begin{tabular}{ccccc}
\hline \multicolumn{5}{c}{ UV-Vis Spectrophotometric Working Conditions } \\
\hline Analyte & Wavelength $(\mathbf{n m})$ & Band Pass $(\mathbf{n m})$ & Cell Type & Cell Length (cm) \\
\hline $\mathrm{NO}_{3}{ }^{-}$ & 220 and 275 & 1.8 & Quartz & 1.0 \\
$\mathrm{PO}_{4}{ }^{3-}$ & 690 & 2.5 & Quartz & 1.0 \\
\hline \multicolumn{4}{c}{ Flame Photometric Working Conditions } \\
\hline Analyte & Wavelength (nm) & Flame System \\
\hline $\mathrm{Na}$ & 589 & Air/ ${ }_{4} \mathrm{H}_{10}$ \\
$\mathrm{~K}$ & 769 & Air/ ${ }_{4} \mathrm{H}_{10}$ \\
\hline
\end{tabular}

Chain of Quality Assurance/Control for Laboratory Sample Analyses

To assure and control the quality of data from sample analysis series of events like calibration of analytical balance, cleaning of laboratory glassware, preparation of stock solutions, working standard solutions, calibration standard solutions, spiking metal standard mixture solution, calibration blanks/instrument blanks, continuing calibration standards, laboratory reagent blank and laboratory fortified blank, laboratory fortified matrix (LFM) and LFM duplicates, sample digestion, estimation of detection limits, and statistical data treatment were carefully carried out.

\section{Cleaning of Laboratory Glassware}

All the glass wares and apparatus used through the entire analysis were first washed with tap water and detergent (except in case of $\mathrm{PO}_{4}{ }^{3-}$ in which chromic acid was used). Next, rinsed with distilled water and followed by $10 \%(\mathrm{v} / \mathrm{v}) \mathrm{HNO}_{3}$ solution. Finally, rinsed again with distilled water and air dried to ensure that free from contamination.

\section{Calibration of Analytical Balance}

AA-200DS Model analytical balance was calibrated first properly using a known $100 \mathrm{~g}$ calibration weight provided with the instrument by the manufacturer. Seven replicate measurements were taken with the experimental mean $99.9937 \mathrm{~g}$, which was compared with a known 100 $\mathrm{g}$ by using t-test (calculated using equation 1). At $95 \% \mathrm{CL}$, there is no significant difference between the experimental mean and a known $(\mu) 100 \mathrm{~g}$. Therefore, the analytical balance was ready for use.

$$
|t|=(\bar{x}-\mu) \frac{\sqrt{n}}{S D}
$$

where $\bar{x}$ is the experimental mean, SD is the standard deviation and $n$ is the number of measurements (Miller, 2010).

\section{Stock standard Solutions}

Stock solutions of concentrations $1000 \mathrm{mg} / \mathrm{L}$ were prepared in laboratory using standard methods.

\section{Working Standard Solutions}

Working standard solutions (100 mg/L) were prepared by diluting accurately measured $10 \mathrm{~mL}$ of individual stock solutions in a separate $100 \mathrm{~mL}$ volumetric flasks to the mark with distilled water.

\section{Calibration Standard Solutions}

Six point calibration standards (including calibration blanks) were prepared from the respective working standard solutions of the analytes analyzed by instrumental methods. The calibration standard concentrations were within the working linear range of the instruments used for the analyses.

\section{Calibration Blanks/Instrument Blanks}

Distilled water was used as a calibration blank for $\mathrm{Na}$ and $\mathrm{K}$ determination. Distilled water treated with $1 \mathrm{~mL}$ of $8.3 \%(\mathrm{v} / \mathrm{v}) \mathrm{HCl}$ was prepared as a calibration blank for $\mathrm{NO}_{3}{ }^{-}$determination. Distilled water treated with $4 \mathrm{~mL}$ of ammonium molybdate solution and $0.5 \mathrm{~mL}$ of stannous chloride reagent was prepared as a calibration blank for $\mathrm{PO}_{4}{ }^{3-}$ determination.

\section{Continuing Calibration Standards}

Continuing Calibration Standards (CCS) was used to ensure calibration accuracy during every analytical run. The CCS represents the value of the midpoint of initial calibration standard. Thus, $2.5 \mathrm{mg} / \mathrm{L}$ for $\mathrm{Na}$ and $\mathrm{K}$, and 1.0 $\mathrm{mg} / \mathrm{L}$ for $\mathrm{NO}_{3}{ }^{-}$and $\mathrm{PO}_{4}{ }^{3-}$ were prepared separately as CCS. CCS was verified after every twenty measurements for each analyte.

\section{Laboratory Reagent Blank and Laboratory Fortified Blank}

Laboratory Reagent Blank (LRB) was used to determine the contribution of the reagents and the preparative analytical steps to error in the measurements. Laboratory Fortified Blank (LFB) was used to evaluate laboratory performance and analyte recovery in a blank matrix. Therefore, a distilled water consist of all reagents that normally are in contact with a sample during the entire analytical procedure was used as LRB whereas a distilled water that spiked with a known concentrations of the analytes of interest was used as LFB.

\section{Laboratory Fortified Matrix (LFM) and LFM Duplicates}

Laboratory-fortified matrix (LFM) was used to evaluate analyte recovery in a sample matrix. LFM were prepared by spiking an additional portion of samples with known amounts of the analytes of interest in five replicates, and processed through all of the sample preparation and analysis steps. The duplicates of LFM were performed in similar way.

\section{Estimation of Instruments Detection Limits (IDL) and Methods Detection Limits (MDL)}

The IDL for each analyte was determined from seven replicate measurements the respective calibration blank at a specific wavelength of that analyte (USEPA, 2007). The IDL were calculated by using the following equation:

$$
\mathrm{IDL}=\mathrm{SD} \times 3
$$

where, SD is the standard deviation of the seven replicates of calibration blanks. 


\section{Habtamu Abdisa and Alemayehu Abebaw}

The MDL of each analyte was determined from seven replicate measurements of distilled water sample spiked with the target analyte at concentrations four times of its IDL. A blank was also processed along with it to measure background contaminations. The MDL was calculated by using the following equation:

$$
\mathrm{MDL}=\mathrm{SD} \times \mathrm{t}
$$

where SD is standard deviation, $t$ is obtained from "Student's t value Table", corresponding to $\mathrm{n}$ - 1 degree of freedom at a defined confidence level (Zhang, 2007).

\section{Evaluation of Analytical Precision, Accuracy and Recovery}

Accuracy of the analytical methods was evaluated in terms of \%recoveries from LFB, LFM and CCS. The analytical method precision was assessed in terms of relative percent differences (RPD), relative standard deviation (RSD) and standard deviations (SD) among measurements.

The \%recoveries were estimated according to the following equation (Zhang, 2007):

$\%$ Recovery on spike $=\frac{\text { Spiked sample value }- \text { Sample value }}{\text { Spiked value }} \times 100$

The RPD were determined from the following equation (APHA, 1999):

$\% \mathrm{RPD}=\frac{\text { LFM or LFB result }- \text { duplicate result }}{(\text { LFM or LFB result }+ \text { duplicate result }) / 2} \times 100$

The SD was assessed using equation (Skoog et al., 2014; Miller, 2010):

$$
\mathrm{SD}=\sqrt{\frac{\sum(\mathrm{xi}-\overline{\mathrm{x}})^{2}}{\mathrm{n}-1}}
$$

where, $x_{i}$ represents the individual values of $x$ making up the set of $\mathrm{n}$ replicate measurements and $\bar{x}$ is the mean value.

The RSD was estimated using the equation:

$$
\operatorname{RSD}=\frac{S D}{\bar{x}} \times 100=C V \times 100
$$

where, CV denotes coefficient of variation $\left(C V=\frac{S D}{\bar{x}}\right)$ (Skoog et al., 2014; Miller, 2010).
Sci. Technol. Arts Res. J., April-June 2014, 3(2): 103-112

\section{Statistical Analysis}

The obtained data were also treated with one-way ANOVA to assess the variations of the parameters among the spring water samples and sediment samples analyzed by using IBM SPSS Statistics 20 version software.

\section{RESULTS AND DISCUSSION}

\section{Methods Validation}

To validate the analytical performance of the instrumental analysis the determination of instrument and method detection limit, the analysis of initial and continuing calibration standards, Laboratory Fortified Blank (LFB) and LFB duplicate Analysis, and Laboratory Fortified Matrix (LFM) and LFM duplicate Analysis were done for each analyte.

\section{Detection Limits}

The Method Detection Limits (MDL) of the analytical methods for each analyte were determined from seven replicates of reagent water spiked with the target analyte at a concentration four times the predetermined Instrument Detection Limit (IDL) of each analyte. These calculated values (Table 2) represent the measured minimum concentration of the analytes and the values reported with $99 \%$ confidence that the analyte concentration greater than zero. The acceptability of the determined MDL was tested by comparing with the spike level, 10 times of calculated MDL, and also evaluated in terms of recovery and RSD. According to Wisconsin Department of Natural Resources (1996), the following inequalities are useful for evaluating a calculated MDL: Calculated MDL < Spike Level < $10 \times$ Calculated MDL

When we come across the calculated data (Table 2), these inequalities conditions are met verifying the acceptability of determined MDL. Also, the recovery and RSD of the calculated MDL are within the required limit: $80-20 \%$ for recovery and $\leq 20 \%$ for RSD (APHA, 1999). These show that the methods are well validated for the determination of the analytes.

\section{Initial Calibration Standards}

Calibration curves showing emission/absorbance versus concentrations were constructed through direct analysis of six point calibration standards (including the instrument blanks) at a specified wavelength of the analytes. The calibration curves showed good correlation coefficients $\left(R^{2}\right)$ greater than the minimum acceptance value of 0.995 (APHA, 1999). This showed that there was a good linear relationship between concentrations and the

\begin{tabular}{|c|c|c|c|c|c|c|c|c|c|}
\hline Technique & Analyte & $\begin{array}{c}\text { Regression } \\
\text { Equation } \\
\left(Y^{\star}=m^{\dagger} X^{\star *}+b^{\#}\right)\end{array}$ & $\begin{array}{c}\text { Correlation } \\
\text { Coefficient } \\
\left(\mathbf{R}^{2}\right)\end{array}$ & $\begin{array}{c}\text { IDL } \\
(\mathrm{mg} / \mathrm{L})\end{array}$ & $\begin{array}{l}\text { Spike } \\
\text { Level } \\
\text { (mg/L) }\end{array}$ & $\begin{array}{c}M D L \\
(\mathrm{mg} / \mathrm{L})\end{array}$ & $\begin{array}{c}10 x \\
\text { MDL } \\
(\mathrm{mg} / \mathrm{L})\end{array}$ & $\begin{array}{l}\text { Reco } \\
\text { very } \\
(\%)\end{array}$ & $\begin{array}{l}\text { RSD } \\
(\%)\end{array}$ \\
\hline \multirow{2}{*}{$\begin{array}{c}\text { Flame } \\
\text { Photometry }\end{array}$} & $\mathrm{Na}$ & $Y=1.0017 X+0.0114$ & 0.9980 & 0.2 & 0.8 & 0.3 & 3.0 & 96.43 & 9.80 \\
\hline & $\mathrm{K}$ & $Y=0.9825 X+0.048$ & 0.9987 & 0.1 & 0.4 & 0.2 & 2.0 & 85.71 & 15.59 \\
\hline \multirow{2}{*}{$\begin{array}{c}\text { UV-Vis } \\
\text { Spectro- } \\
\text { photometry }\end{array}$} & $\mathrm{NO}_{3}^{-}$ & $Y=0.2415 X+0.0009$ & 0.9997 & 0.063 & 0.25 & 0.1 & 1.0 & 89.3 & 12.43 \\
\hline & $\mathrm{PO}_{4}{ }^{3-}$ & $Y=0.3061 X+0.0035$ & 0.9995 & 0.057 & 0.23 & 0.09 & 0.9 & 94.39 & 10.68 \\
\hline
\end{tabular}
instrument responses.

Table 2: Regression equations, correlation coefficients and detection limits. 
Habtamu Abdisa and Alemayehu Abebaw

\section{Continuing Calibration Standards (CCS)}

Accuracy of the instrument calibrations were tested through analysis of separately prepared solutions at a mid-point concentration of calibration standards for each analyte after every twenty measurements. Since 101 total samples (except 67 for $\mathrm{PO}_{4}{ }^{3-}$ ) were analyzed for each analyte, a CCS was checked five times and the recoveries
Sci. Technol. Arts Res. J., April-June 2014, 3(2): 103-112

for each analysis are given in Table 3. According to the standard methods of analysis, the continuing calibration standards should be within $\pm 20 \%$ of $100 \%$ accuracy (APHA, 1999). Therefore, the recoveries from the analysis of CCS for all the analytes were within this limit confirming accuracy of the calibrations.

Table 3: Percent recoveries from the analysis of continuing calibration standards (CCS).

\begin{tabular}{ccccccc}
\hline \multirow{2}{*}{ Analyte } & $\begin{array}{c}\text { Prepared } \\
\text { Concentration } \\
(\mathbf{m g} / \mathbf{L})\end{array}$ & CCS-1 & CCS-2 & CCS-3 & CCS-4 & CCS-5 \\
\cline { 3 - 7 } & 2.5 & 98.40 & 92.00 & 93.60 & 96.00 & 92.80 \\
$\mathrm{Na}$ & 2.5 & 89.20 & 97.60 & 98.00 & 95.20 & 94.40 \\
$\mathrm{~K}$ & 1.0 & 97.19 & 98.03 & 97.61 & 98.45 & 96.76 \\
$\mathrm{NO}_{3}{ }^{-}$ & 1.0 & 95.42 & 96.78 & 96.44 & & \\
$\mathrm{PO}_{4}{ }^{3-}$ & & & & &
\end{tabular}

\section{Laboratory Fortified Blank (LFB) and LFB duplicate Analysis}

To assess the overall contamination during the laboratory sample analysis, LFB were carried out in five replicates along with the samples through the entire digestion and analysis process. Furthermore, to evaluate the efficiency of the analysis five replicates of LFB duplicate were passed through the same procedure as LFB and samples. Consequently, the mean recoveries were calculated from LFB and LFB duplicate fortified at a mid-point of calibration standards, and the values are given in Table 4. The RPD between the mean recoveries of LFB and LFB duplicates were also calculated to evaluate the data quality.

According to the standard methods, if no acceptance criteria are provided by chosen laboratory, $80-120 \%$ recovery and $\leq 20 \%$ RSD can used as a starting point for assessment of accuracy and precision (APHA, 1999). Therefore, the mean recovery values were found between the lowest 86.44 and highest $98.91 \%$, and all were within the required criteria of $80-120 \%$. Also, the RPD values (Table 4) were below the required limit $(<15 \%$, APHA, 1999). This confirmed that the method has provided results within the required levels of accuracy and precision.

\section{Laboratory Fortified Matrix (LFM) and LFM Duplicate Analysis}

LFM and LFM duplicates were studied along with the sample analysis to monitor the overall sample matrixdependent accuracy and precision of the analytical methods. Consequently, the recovery values were determined from the analysis of actual samples spiked with mid-point of calibration standards of each analyte. Both LFM and LFM duplicates were passed through the entire analysis steps along with the samples. To control the method precision, the RPD values among LFM and LFM duplicate recoveries were also evaluated. The results are given in Table 5 .

As shown in Table 5, both the LFM and LFM duplicate mean recoveries were found between 83.07 and $110.57 \%$, which all were within the recommended range for matrix spike recovery $75-125 \%$ (APHA, 1999). This indicated that the method has provided the required matrix-dependant accuracy. The determined RPD were found between $2.59\left(\mathrm{PO}_{4}{ }^{3-}\right.$ in Ittisa) and $13.50 \%$ ( $\mathrm{Na}$ in Ittisa) which all were within the acceptance criteria $( \pm 15 \%$ difference). Therefore, the methods were well applicable for all the matrices within a good precision.

Table 4: Percent recoveries from LFB and LFB duplicates.

\begin{tabular}{lccc}
\hline Analyte & LFB Mean ${ }^{*}$ recovery (\%) & $\begin{array}{c}\text { LFB duplicate Mean } \\
\text { recovery (\%) }\end{array}$ & $\begin{array}{c}\text { RPD between } \\
\text { the two mean }\end{array}$ \\
\hline $\mathrm{Na}$ & $95.70 \pm 2.16$ & $87.20 \pm 1.79$ & 9.30 \\
$\mathrm{~K}$ & $92.00 \pm 2.83$ & $97.60 \pm 4.56$ & 5.91 \\
$\mathrm{NO}_{3}{ }^{-}$ & $96.04 \pm 4.30$ & $88.95 \pm 4.90$ & 7.67 \\
$\mathrm{PO}_{4}{ }^{3-}$ & $98.21 \pm 1.04$ & $94.45 \pm 0.86$ & 3.90 \\
\hline
\end{tabular}

\section{Analyses of Physicochemical Parameters}

The summary of the results (mean \pm SD) for physicochemical and major chemical analyses are given in Table 6. The results were compared with the World Health Organization (WHO, 2011) and Ethiopian guidelines (2011) for drinking water (Table 6).

Temperature: The measurements were made during morning time, daytime and late afternoon, in the gap of 4 hours, to observe the diurnal variation in water temperature. Thus, the variation of the temperature during the investigation was small with the ranges of $1.5^{\circ} \mathrm{C}$, $1.7^{\circ} \mathrm{C}, 1.3^{\circ} \mathrm{C}, 1.0^{\circ} \mathrm{C}$ and $2.0^{\circ} \mathrm{C}$ at site of Ittisa, Abba Moga, Kersa, Ele Gonda and Merfata, respectively. According to Weiner (2008), the maximum induced change in water temperature is limited to a $3^{\circ} \mathrm{C}$ increase over a 4 hours period. Then, the observed diurnal variation for temperature on each site is below this limit and no changes harmful for consumption of the water. The reported results (Table 6) are the average of the three time-gap measurements that were taken as the average of five replicates at each spring sources. Then, the measured temperature values were varied from $20.5^{\circ} \mathrm{C}$ to $22.0^{\circ} \mathrm{C}$ at Ittisa; $20.0^{\circ} \mathrm{C}$ to $21.7^{\circ} \mathrm{C}$ at Abba Moga; $19.0^{\circ} \mathrm{C}$ to $20.3^{\circ} \mathrm{C}$ at Kersa; 21.0 to $22 .{ }^{\circ} \mathrm{C}$ at Ele Gonda; and $19.0^{\circ} \mathrm{C}$ to $21.0^{\circ} \mathrm{C}$ at Merfata Spring. One-way ANOVA test $(P=0.05)$ showed that the temperatures varied significantly between the springs. This could be from the variation in air temperature and the amount of shade around the springs. 


\section{Habtamu Abdisa and Alemayehu Abebaw}

pH: The $\mathrm{pH}$ were also measured during morning time, daytime and late afternoon along with temperature and the average of the three time-gap measurements were reported (Table 6). The $\mathrm{pH}$ at-site of Ittisa, Abba Moga, Kersa, Ele Gonda and Merfata was ranged from 6.5 to $7.0,6.4$ to $7.1,6.7$ to $7.2,6.6$ to 7.2 , and 6.9 to 7.9 , respectively. The obtained results indicated that all the five spring sources are nearly neutral. All the mean values of $\mathrm{pH}$ are within the limit of $\mathrm{WHO}$ and Ethiopian standards for drinking water quality indicating that the corrosive ability of water on the piping system is small. The results of one-way ANOVA $(P=0.05)$ indicated that the $\mathrm{pH}$ among the studied waters varied significantly owing to the variation of alkalinity among the springs.

Electrical Conductivity (EC): Like temperature and $\mathrm{pH}$, the EC was measured during morning time, daytime and late afternoon and the average of the three time-gap measurements was taken (Table 6). The mean values were found between the minimum mean $22.1 \mu \mathrm{S} / \mathrm{cm}$ (Merfata) and the maximum mean $47.1 \mu \mathrm{S} / \mathrm{cm}$ (Ittisa). Analysis of one-way ANOVA ( $p=0.05$ ) indicted that the EC among the water springs varied significantly. This could be due to the variation of TDS among the water springs. The current study gave the results below the $\mathrm{WHO}$ and Ethiopian guidelines for drinking water quality. Therefore, no problem concerned with EC if the waters to be used for drinking.

Total Dissolved Solids (TDS): According to WHO (2011), the palatability of water with a TDS level of less than about $600 \mathrm{mg} / \mathrm{L}$ is generally considered to be good. The measured TDS values were found between the minimum mean value of $17.8 \mathrm{mg} / \mathrm{L}$ (Merfata) and
Sci. Technol. Arts Res. J., April-June 2014, 3(2): 103-112

maximum mean value of $33.3 \mathrm{mg} / \mathrm{L}$ (Ittisa). The results were below the $\mathrm{WHO}$ and Ethiopian guidelines for drinking water quality indicating that no palatability problem concerned with TDS of the studied waters. Oneway ANOVA test $(p=0.05)$ showed that the TDS among the studied waters varied significantly owing to the variation of dissolved minerals between the springs.

Chemical Oxygen Demand (COD): The COD was calculated using following equation:

$$
\text { COD as } \mathrm{mg} \mathrm{O}_{2} / \mathrm{L}=\frac{(\mathrm{A}-\mathrm{B}) \times \mathrm{N} \times 8,000}{\text { Volume }(\mathrm{mL}) \text { of water sample }}
$$

where $A$ is the $m L$ of ferrous ammonium sulfate (FAS) used for blank, $B$ is the $\mathrm{mL}$ of FAS used for water sample, and $\mathrm{N}$ is the normality of FAS (Zhang, 2007; APHA, 1999). Ferrous ammonium sulfate was used for back titration with the excess dichromate after the completion of sample digestion according to the following chemical reaction:

$6 \mathrm{Fe}^{2+}+\mathrm{Cr}_{2} \mathrm{O}_{7}{ }^{2-}+14 \mathrm{H}^{+} \longrightarrow 6 \mathrm{Fe}^{3+}+2 \mathrm{Cr}^{3+}+7 \mathrm{H}_{2} \mathrm{O}$

The COD mean values were found between the minimum value $5.12 \mathrm{mg} / \mathrm{L}$ (Kersa) and maximum value $8.06 \mathrm{mg} / \mathrm{L}$ (Ittisa), as shown in Table 6. No COD standard has been prescribed by WHO and Ethiopian guidelines of drinking water quality, but all COD values are lower than the maximum accepted value $(10 \mathrm{mg} \mathrm{O} / \mathrm{L})$ of the Pakistanian standard (2008) for drinking water. One-way ANOVA test $(p=0.05)$ found that the COD between the investigated waters varied significantly indicating that the organic and oxidizable inorganic matters between the water springs varied.

Table 5: Percent recoveries from LFM and LFM duplicates.

\begin{tabular}{|c|c|c|c|c|}
\hline Spring Site & Analyte & $\begin{array}{l}\text { LFM mean } \\
\text { recovery }(\%)\end{array}$ & $\begin{array}{c}\text { LFM duplicate } \\
\text { mean }^{\star} \text { recovery (\%) }\end{array}$ & $\begin{array}{l}\text { RPD between } \\
\text { the two mean }\end{array}$ \\
\hline \multirow{4}{*}{ Ittisa } & $\mathrm{Na}$ & $95.52 \pm 1.75$ & $83.44 \pm 3.32$ & 13.50 \\
\hline & $\mathrm{K}$ & $102.40 \pm 4.56$ & $94.60 \pm 2.36$ & 7.96 \\
\hline & $\mathrm{NO}_{3}{ }^{-}$ & $103.65 \pm 4.76$ & $110.57 \pm 5.30$ & 6.47 \\
\hline & $\mathrm{PO}_{4}{ }^{3-}$ & $95.36 \pm 4.24$ & $97.87 \pm 3.26$ & 2.59 \\
\hline \multirow{4}{*}{ Abba Moga } & $\mathrm{Na}$ & $106.88 \pm 4.36$ & $98.40 \pm 2.19$ & 8.26 \\
\hline & $\mathrm{K}$ & $97.60 \pm 3.57$ & $93.80 \pm 2.03$ & 3.93 \\
\hline & $\mathrm{NO}_{3}{ }^{-}$ & $87.09 \pm 2.19$ & $90.30 \pm 4.16$ & 3.62 \\
\hline & $\mathrm{PO}_{4}{ }^{3-}$ & $97.41 \pm 2.00$ & $93.09 \pm 4.82$ & 4.54 \\
\hline \multirow{4}{*}{ Kersa } & $\mathrm{Na}$ & $95.20 \pm 4.56$ & $102.40 \pm 3.60$ & 7.29 \\
\hline & $\mathrm{K}$ & $92.24 \pm 2.55$ & $98.40 \pm 2.20$ & 6.46 \\
\hline & $\mathrm{NO}_{3}{ }^{-}$ & $97.57 \pm 3.34$ & $93.00 \pm 4.04$ & 4.80 \\
\hline & $\mathrm{PO}_{4}{ }^{3-}$ & $83.07 \pm 3.81$ & $90.81 \pm 1.77$ & 8.90 \\
\hline \multirow{4}{*}{ Ele Gonda } & $\mathrm{Na}$ & $92.80 \pm 3.58$ & $104.16 \pm 3.06$ & 11.53 \\
\hline & $\mathrm{K}$ & $91.20 \pm 3.30$ & $95.40 \pm 3.89$ & 4.54 \\
\hline & $\mathrm{NO}_{3}^{-}$ & $107.79 \pm 3.00$ & $99.68 \pm 4.52$ & 7.80 \\
\hline & $\mathrm{PO}_{4}{ }^{3-}$ & $91.49 \pm 4.69$ & $86.49 \pm 4.34$ & 5.63 \\
\hline \multirow{4}{*}{ Merfata } & $\mathrm{Na}$ & $91.68 \pm 2.30$ & $96.48 \pm 3.64$ & 5.10 \\
\hline & $\mathrm{K}$ & $84.90 \pm 3.47$ & $96.80 \pm 3.34$ & 13.12 \\
\hline & $\mathrm{NO}_{3}^{-}$ & $96.04 \pm 4.77$ & $92.83 \pm 3.89$ & 3.40 \\
\hline & $\mathrm{PO}_{4}{ }^{3-}$ & $89.56 \pm 2.40$ & $92.97 \pm 3.78$ & 3.74 \\
\hline
\end{tabular}

Measurements were made in five replicates except three replicates for $\mathrm{PO}_{4}{ }^{3-}$ recoveries. 
Table 6: Results $\left(\right.$ Mean ${ }^{\star} \pm \mathrm{SD}^{\dagger}$ ) for physicochemical and major chemical parameters of spring water samples.

\begin{tabular}{|c|c|c|c|c|c|c|c|}
\hline \multirow{2}{*}{ Parameter } & \multicolumn{5}{|c|}{ Spring Sites } & \multicolumn{2}{|c|}{$\begin{array}{l}\text { Guidelines for } \\
\text { Drinking Water }\end{array}$} \\
\hline & Ittisa & Abba Moga & Kersa & Ele Gonda & Merfata & $\begin{array}{l}\text { WHO, } \\
2011\end{array}$ & $\begin{array}{l}\text { FDRE }^{\#}, \\
2011\end{array}$ \\
\hline Temperature $\left({ }^{\circ} \mathrm{C}\right)$ & $21.07 \pm 0.35$ & $20.85 \pm 0.52$ & $19.78 \pm 0.42$ & $21.57 \pm 0.38$ & $19.92 \pm 0.71$ & - & - \\
\hline $\mathrm{pH}$ & $6.67 \pm 0.14$ & $6.76 \pm 0.20$ & $7.01 \pm 0.15$ & $6.90 \pm 0.16$ & $7.44 \pm 0.27$ & $6.5-8.5$ & $\begin{array}{l}6.5- \\
8.5\end{array}$ \\
\hline $\mathrm{EC}(\mu \mathrm{S} / \mathrm{cm})$ & $47.10 \pm 2.46$ & $46.40 \pm 1.35$ & $27.80 \pm 0.94$ & $35.80 \pm 1.42$ & $22.10 \pm 2.56$ & - & - \\
\hline TDS (mg/L) & $32.90 \pm 0.50$ & $31.60 \pm 0.55$ & $18.00 \pm 0.71$ & $28.20 \pm 0.84$ & $17.80 \pm 0.45$ & 1000 & 1000 \\
\hline $\begin{array}{l}\mathrm{COD} \text { (as mg } \\
\left.\mathrm{O}_{2} / \mathrm{L}\right)\end{array}$ & $8.06 \pm 0.76$ & $7.42 \pm 0.58$ & $5.12 \pm 0.44$ & $6.78 \pm 0.22$ & $5.38 \pm 0.38$ & - & - \\
\hline Alkalinity (mg/L) & $5.76 \pm 0.80$ & $6.12 \pm 0.40$ & $7.20 \pm 0.64$ & $6.48 \pm 0.75$ & $7.56 \pm 0.49$ & - & 200 \\
\hline $\begin{array}{l}\text { Total Hardness } \\
(\mathrm{mg} / \mathrm{L})\end{array}$ & $27.60 \pm 0.91$ & $25.20 \pm 1.79$ & $18.80 \pm 1.10$ & $23.60 \pm 0.89$ & $18.00 \pm 1.41$ & 200 & 300 \\
\hline $\mathrm{Ca}(\mathrm{mg} / \mathrm{L})$ & $7.37 \pm 0.22$ & $7.05 \pm 0.36$ & $5.13 \pm 0.33$ & $6.41 \pm 0.57$ & $4.49 \pm 0.72$ & - & 75 \\
\hline $\mathrm{Mg}(\mathrm{mg} / \mathrm{L})$ & $2.23 \pm 0.32$ & $1.84 \pm 0.21$ & $1.45 \pm 0.17$ & $1.85 \pm 0.22$ & $1.65 \pm 0.27$ & - & 50 \\
\hline $\mathrm{Cl}^{-}(\mathrm{mg} / \mathrm{L})$ & $4.10 \pm 0.42$ & $3.10 \pm 0.22$ & $4.00 \pm 0.35$ & $5.30 \pm 0.27$ & $3.80 \pm 0.44$ & 250 & 250 \\
\hline $\mathrm{SO}_{4}{ }^{2-}(\mathrm{mg} / \mathrm{L})$ & $2.53 \pm 0.25$ & $2.15 \pm 0.20$ & $2.35 \pm 0.18$ & $1.74 \pm 0.10$ & $1.84 \pm 0.27$ & 250 & 250 \\
\hline $\mathrm{Na}(\mathrm{mg} / \mathrm{L})$ & $1.14 \pm 0.05$ & $1.50 \pm 0.10$ & $1.58 \pm 0.13$ & $1.12 \pm 0.08$ & $1.20 \pm 0.07$ & 200 & 200 \\
\hline $\mathrm{K}$ (mg/L) & $0.610 \pm 0.007$ & $0.801 \pm 0.008$ & $0.706 \pm 0.005$ & $0.626 \pm 0.005$ & $0.728 \pm 0.004$ & - & 1.5 \\
\hline $\mathrm{NO}_{3}{ }^{-}(\mathrm{mg} / \mathrm{L})$ & $0.767 \pm 0.022$ & $0.868 \pm 0.082$ & $0.774 \pm 0.072$ & $0.618 \pm 0.021$ & $0.703 \pm 0.095$ & 50 & 50 \\
\hline $\mathrm{PO}_{4}{ }^{3-}(\mathrm{mg} / \mathrm{L})$ & $0.314 \pm 0.026$ & $0.290 \pm 0.014$ & $0.254 \pm 0.029$ & $0.213 \pm 0.012$ & $0.234 \pm 0.025$ & - & - \\
\hline
\end{tabular}

"Mean values are calculated from five replicates except three for COD and $\mathrm{PO}_{4}{ }^{3-}$ determination; ${ }^{\dagger} \mathrm{SD}=\mathrm{Standard}$ Deviation and "FDRE = Federal Democratic Republic of Ethiopia.

Alkalinity: The alkalinity was calculated using following equation:

Total alkalinity, $\left(\mathrm{mg} \mathrm{CaCO}_{3}\right) / \mathrm{L}=\frac{(\mathrm{C}+\mathrm{D}) \times \mathrm{N} \times 50,000}{\mathrm{~V}}$

where $\mathrm{C}$ is the volume in $\mathrm{mL}$ of $\mathrm{HCl}$ solution used to reach $\mathrm{pH}=8.3, \mathrm{D}$ is the volume in $\mathrm{mL}$ of $\mathrm{HCl}$ solution used to reach $\mathrm{pH}=4.4, \mathrm{~N}$ is the concentration of standard $\mathrm{HCl}$ solution in normality, and $\mathrm{V}$ is the volume of water sample in $\mathrm{mL}$ (Maiti, 2004).

The obtained values are due to methyl orange alkalinity (at about $\mathrm{pH} 4.5$ ) because the phenolphthalein alkalinity $(\mathrm{P})$ which is expected at about $\mathrm{pH} 8.3$ in each sites are zero. The major portion of alkalinity in natural waters is caused by hydroxide, carbonate, and bicarbonate. According to the standard methods (APHA, 1999), when $\mathrm{P}=0$ the $\mathrm{OH}^{-}$alkalinity and $\mathrm{CO}_{3}{ }^{2-}$ alkalinity are zero while $\mathrm{HCO}_{3}{ }^{-}$alkalinity is equal with total alkalinity. Therefore, the observed alkalinity is possibly due to $\mathrm{HCO}_{3}{ }^{-}$from dissolved $\mathrm{CO}_{2}$. The present study result of total alkalinity was found between the minimum mean of $5.76 \mathrm{mg} / \mathrm{L}$ (Ittisa) and the maximum mean of $7.56 \mathrm{mg} / \mathrm{L}$ (Merfata) as shown in Table 3 . The results indicate that Merfata spring contains high bicarbonates, which react with $\mathrm{H}^{+}$ions from the water thereby raising the $\mathrm{pH}$ of the water. The determined mean values were below the WHO and Ethiopian guidelines for drinking water indicating that no unpleasant taste associated with the alkalinity of the studied waters. The ANOVA test $(p=0.05)$ showed that the alkalinity among the waters varied considerably owing to the variation of bicarbonates.

Total Hardness: The mean values was varied between the minimum value18 $\mathrm{mg} / \mathrm{L}$ in Merfata and the maximum value $27.6 \mathrm{mg} / \mathrm{L}$ in Ittisa (Table 6), and all were below the $\mathrm{WHO}$ and Ethiopian guidelines for drinking water indicating that no hardness related problems like scale formation in water pipes and soap consuming property of waters.

The total hardness was determined by EDTA titration method and calculated by using the following equation:

Total hardness $\left(\right.$ as $\left.\mathrm{CaCO}_{3} \mathrm{mg} / \mathrm{L}\right)=\frac{\mathrm{A} \times \mathrm{B} \times 1000}{\text { Volume }(\mathrm{mL}) \text { of sample }}$

where, $A$ is the volume in $\mathrm{mL}$ of $0.01 \mathrm{M}$ EDTA required by sample for titration and $\mathrm{B}$ is the $\mathrm{mg} \mathrm{CaCO}_{3}$ equivalent to $1 \mathrm{~mL}$ EDTA titrant (APHA, 1999).

One-way ANOVA test $(p=0.05)$ showed that the total hardness values among the water springs varied significantly. This is could be due to the variation of hardness causing cations and anions like $\mathrm{Ca}^{2+}, \mathrm{Mg}^{2+}$, $\mathrm{Fe}^{2+}, \mathrm{Mn}^{2+}, \mathrm{SO}_{4}{ }^{2-}, \mathrm{NO}_{3}{ }^{-}, \mathrm{Cl}^{-}$and $\mathrm{HCO}_{3}{ }^{-}$), as observed from the analyses.

\section{Major Chemical Parameters}

The results are given in Table 3, along with physicochemical parameters.

Calcium (Ca) and Magnesium (Mg): The source of $\mathrm{Ca}$ and $\mathrm{Mg}$ is the rocks from which it is leached. $\mathrm{Ca}$ is determined by EDTA titration method and calculated in $\mathrm{mg} / \mathrm{L}$ by using the following formula:

$\mathrm{mg} \mathrm{Ca} / \mathrm{L}=\frac{\mathrm{A} \times \mathrm{B} \times 400.8}{\text { Volume }(\mathrm{mL}) \text { of sample }}$

where, $A$ is the volume in $\mathrm{mL}$ of $0.01 \mathrm{M}$ EDTA required by sample for titration and $\mathrm{B}$ is the $\mathrm{mg} \mathrm{CaCO}_{3}$ equivalent to $1 \mathrm{~mL}$ EDTA titrant (APHA, 1999). 
Habtamu Abdisa and Alemayehu Abebaw

$\mathrm{Mg}$ is calculated from the $\mathrm{Ca}$ concentration and $\mathrm{TH}$, using the following equation:

$\mathrm{Mg}($ in $\mathrm{mg} / \mathrm{L})=\left(\mathrm{TH}\left(\mathrm{mg} \mathrm{CaCO}_{3} / \mathrm{L}\right)-2.497(\mathrm{Ca}, \mathrm{mg} / \mathrm{L})\right) /$ 4.118

where $\mathrm{TH}$ represents the total hardness, 2.497 is the multiplying factor for $\mathrm{Ca}^{2+}$ as $\mathrm{CaCO}_{3}$ which is calculated by dividing the equivalent weight of $\mathrm{CaCO}_{3}$ to the equivalent weight of $\mathrm{Ca}^{2+}$, and 4.118 is the multiplying factor for $\mathrm{Mg}^{2+}$ as $\mathrm{CaCO}_{3}$ which is calculated by dividing the equivalent weight of $\mathrm{CaCO}_{3}$ to the equivalent weight of $\mathrm{Mg}^{2+}$.

The $\mathrm{Ca}$ and $\mathrm{Mg}$ of the investigated spring waters could be due to the contact between the water body and the rock layers. Because these springs are naturally occurred springs that come out on the earth's surface by crossing rock layers which leach these minerals and others to the water body. The $\mathrm{Ca}$ mean values were ranged from the minimum value $4.49 \mathrm{mg} / \mathrm{L}$ (Merfata) to the maximum of $7.37 \mathrm{mg} / \mathrm{L}$ (Ittisa) and $\mathrm{Mg}$ mean values were ranged from the minimum value $\quad 1.45 \mathrm{mg} / \mathrm{L}$ (Kersa) to $2.23 \mathrm{mg} / \mathrm{L}$ (Ittisa). The study results were below the $\mathrm{WHO}$ and Ethiopian guidelines for drinking water showing that no health problem concerned with $\mathrm{Ca}$ and $\mathrm{Mg}$. One-way ANOVA test $(p=0.05)$ found that both $\mathrm{Ca}$ and $\mathrm{Mg}$ among the studied waters varied significantly. This could be due to the variation in mineral composition of the rocks from which these metals are leached.

Sulphate $\left(\mathrm{SO}_{4}{ }^{2-}\right)$ : $\mathrm{SO}_{4}{ }^{2-}$ is one of the major anions occurring in natural waters (Maiti, 2004). $\mathrm{SO}_{4}{ }^{2-}$ in water is usually expected to atmospheric deposition, industrial runoff, and natural sources such as gypsum $\left(\mathrm{CaSO}_{4}\right.$. $\left.2 \mathrm{H}_{2} \mathrm{O}\right)$ and anhydrite $\left(\mathrm{CaSO}_{4}\right)$ (Saadeh, 2012). The $\mathrm{SO}_{4}{ }^{2-}$ in the studied spring waters is might be due to atmospheric deposition of particulate matter of $\mathrm{SO}_{4}{ }^{2-}$ from the investigated area and natural sources in the waters. The $\mathrm{SO}_{4}{ }^{2-}$ is determined by gravimetric method and calculated using the following formula:

$\mathrm{SO}_{4}{ }^{2-}($ in $\mathrm{mg} / \mathrm{L})=\frac{\mathrm{mg} \mathrm{BaSO} 4 \times 411.6}{\text { Volume }(\mathrm{mL}) \text { of sample }}$

where, the number 411.6 is the product of the gravimetric factor $\left(0.4116\right.$, ratio of formula weight of $\mathrm{SO}_{4}{ }^{2-}$ to $\left.\mathrm{BaSO}_{4}\right)$ and the conversion factor (1000).

The chemical reaction that indicates the precipitation of $\mathrm{SO}_{4}{ }^{2-}$ ions from the sample solution is given as the following equation.

$\mathrm{SO}_{4}{ }^{2-}$ (in water sample) $+\mathrm{BaCl}_{2}$ (aqueous) $\overrightarrow{\mathrm{BaSO}_{4} \text { (white precipitate) }+2 \mathrm{Cl}^{-} \text {(aqueous) }}$

The $\mathrm{SO}_{4}{ }^{2-}$ ions in all springs were ranged from the mean values of $1.74 \mathrm{mg} / \mathrm{L}$ in Ele Gonda to $2.53 \mathrm{mg} / \mathrm{L}$ in Ittisa. The presence of $\mathrm{SO}_{4}{ }^{2-}$ in drinking-water can cause noticeable taste. It is generally considered that taste impairment is minimal at levels below $250 \mathrm{mg} / \mathrm{L}$. The investigated waters have $\mathrm{SO}_{4}{ }^{2-}$ less than the taste threshold value $(<250 \mathrm{mg} / \mathrm{L})$ recommended by $\mathrm{WHO}$ and Ethiopian standards for drinking water, indicating that no problem associated with $\mathrm{SO}_{4}{ }^{2-}$. The One-way ANOVA test $(p=0.05)$ showed that the $\mathrm{SO}_{4}{ }^{2-}$ concentrations among the studied waters varied significantly. This could be due to the variation of the natural sources and the extent of atmospheric deposition of $\mathrm{SO}_{4}{ }^{2-}$ around the springs.
Sci. Technol. Arts Res. J., April-June 2014, 3(2): 103-112

Chloride $\left(\mathrm{Cl}^{-}\right)$: Chloride in drinking-water originates from natural sources, sewage and industrial effluents (WHO, 2011). Therefore, the $\mathrm{Cl}^{-}$ions in the studied springs are possibly due to the natural sources since there are no available industrial sources from the study area. No health-based guideline value is proposed for chloride in drinking water. Because, not of health concern at levels found in drinking-water (WHO, 2011). The $\mathrm{Cl}^{-}$ion was determined by argentometric method and calculated using to the following formula:

$\mathrm{Cl}^{-}($in $\mathrm{mg} / \mathrm{L})=\frac{(\mathrm{A}-\mathrm{B}) \times \mathrm{N} \times 35,450}{\text { Volume }(\mathrm{mL}) \text { of sample }}$

where $A$ is the volume in $\mathrm{mL}$ of $0.0141 \mathrm{~N} \mathrm{AgNO}_{3}$ for sample, $B$ is the volume in $\mathrm{mL}$ of $0.0141 \mathrm{~N} \mathrm{AgNO}_{3}$ for blank, and $\mathrm{N}$ is the normality of $\mathrm{AgNO}_{3}$ (APHA, 1999). The possible chemical reaction for the precipitation of $\mathrm{Cl}^{-}$ions from the water samples is shown as the following chemical equation.

$$
\begin{aligned}
& \mathrm{Cl}^{-} \text {(in water sample) }+\mathrm{AgNO}_{3} \text { (aqueous) } \\
& \qquad \mathrm{AgCl} \text { (white precipitate) }+\mathrm{NO}_{3}^{-} \text {(aqueous) }
\end{aligned}
$$

The $\mathrm{Cl}^{-}$concentration in the investigated water springs were ranged from the minimum value $3.1 \mathrm{mg} / \mathrm{L}$ in Abba Moga to $5.3 \mathrm{mg} / \mathrm{L}$ in Ele Gonda. Chloride may affect acceptability of drinking water by offering a salty taste to water. However, currently determined $\mathrm{Cl}^{-}$values were below the $\mathrm{WHO}$ and Ethiopian guideline values for drinking water, indicating that no taste effects associated with $\mathrm{Cl}^{-}$ions in the studied springs. One-way ANOVA test $\left(p=0.05\right.$ ) showed that the $\mathrm{Cl}^{-}$concentrations among the studied water springs varied significantly owing to the difference in solubility of $\mathrm{Cl}^{-}$salts which may affected by the $\mathrm{pH}$ of the waters.

Sodium ( $\mathrm{Na}$ ): The mean values were ranged from the minimum value of $1.12 \mathrm{mg} / \mathrm{L}$ (Ele Gonda) to the maximum value of $1.58 \mathrm{mg} / \mathrm{L}$ (Kersa). These values were below the drinking water quality guideline value currently recommended by $\mathrm{WHO}$ and Ethiopian standards, indicating no taste problems concerned with $\mathrm{Na}$ in the waters. One-way ANOVA test $(p=0.05)$ found that the $\mathrm{Na}$ concentrations among the studied waters varied significantly. This could be from the variation of cation exchange capacity of water, mainly with $\mathrm{Ca}$ and $\mathrm{Mg}$.

Potassium (K): From the current study, calculated average values of potassium concentrations for each spring was within the range of the mean value $0.610 \mathrm{mg} / \mathrm{L}$ in Ittisa to the maximum value $0.801 \mathrm{mg} / \mathrm{L}$ in Abba Moga. All values were below the maximum value recommended by $\mathrm{WHO}$ and Ethiopian standards for drinking water quality, indicating no health risks concerned with potassium at levels found in these waters. One-way ANOVA test $(p=0.05)$ found that potassium among the water springs varied considerably owing to the variation of naturally occurring potassium salts.

Nitrate $\left(\mathrm{NO}_{3}{ }^{-}\right): \mathrm{NO}_{3}{ }^{-}$is found naturally in the environment and is an important plant nutrient. $\mathrm{NO}_{3}{ }^{-}$can reach both surface water and groundwater as a consequence of agricultural activity (including excess application of inorganic nitrogenous fertilizers and manures), from wastewater disposal and from oxidation of nitrogenous waste products in human and animal excreta (WHO, 
Habtamu Abdisa and Alemayehu Abebaw

2011). The $\mathrm{NO}_{3}^{-}$in the studied waters was possibly resulted from a consequence of agricultural activity. The waste products in human and animal excreta could also contribute to $\mathrm{NO}_{3}{ }^{-}$in the studied waters. However, currently detected $\mathrm{NO}_{3}{ }^{-}$in these waters are mostly due to the natural availability of $\mathrm{NO}_{3}{ }^{-}$in water because the current study was conducted during the dried season which may not contribute to leaching of chemical fertilizers and animal manure. The current study gave the $\mathrm{NO}_{3}{ }_{3}$ concentrations between the minimum mean of $0.618 \mathrm{mg} / \mathrm{L}$ (Ele Gonda) and the maximum mean of $0.868 \mathrm{mg} / \mathrm{L}$ (Abba Moga). The obtained results were below the WHO and Ethiopian guideline values for drinking water quality, indicating that no health problem concerned with $\mathrm{NO}_{3}{ }_{3}^{-}$. One-way ANOVA test $(P=0.05)$ showed that the $\mathrm{NO}_{3}$ concentrations among the water springs varied significantly owing to the differences in its movement with ground water flow.

Phosphate $\left(\mathrm{PO}_{4}{ }^{3-}\right)$ : Water may contain $\mathrm{PO}_{4}{ }^{3-}$ derived from natural contact with minerals or through pollution from application of fertilizer, sewage and industrial waste. Groundwater, therefore, is more likely to have higher $\mathrm{PO}_{4}{ }^{3-}$ concentration (Maiti, 2004). The $\mathrm{PO}_{4}{ }^{3-}$ in the studied spring waters was possibly from the natural contact with minerals when the water bodies come across the layers of various rocks. In this study, $\mathrm{PO}_{4}{ }^{3-}$ was determined by stannous chloride colorimetric method in which the orthophosphate $\left(\mathrm{PO}_{4}{ }^{3-}\right)$ reacts with ammonium molybdate $\left(\left(\mathrm{NH}_{4}\right)_{2} \mathrm{MoO}_{4}\right)$ in acidic media to form molybdophosphoric acid and reduced to blue color complex upon reaction with stannous chloride $\left(\mathrm{SnCl}_{2}\right)$.

$$
\begin{aligned}
& \mathrm{PO}_{4}{ }^{3-}+12\left(\left(\mathrm{NH}_{4}\right)_{2} \mathrm{MoO}_{4}\right)+24 \mathrm{H}^{+} \longrightarrow \\
& \left(\left(\mathrm{NH}_{4}\right)_{3} \mathrm{PO}_{4} .12 \mathrm{MoO}_{3}\right)+21 \mathrm{NH}_{4}^{+}+12 \mathrm{H}_{2} \mathrm{O} \\
& \left(\left(\mathrm{NH}_{4}\right)_{3} \mathrm{PO}_{4} .12 \mathrm{MoO}_{3}\right)+\mathrm{Sn}^{2+} \\
& \text { (molybdenum blue complex) }+\mathrm{Sn}^{4+}
\end{aligned}
$$

(Maiti, 2004).

The obtained results were found between the minimum mean of $0.213 \mathrm{mg} / \mathrm{L}$ (Ele Gonda) and the maximum mean of $0.314 \mathrm{mg} / \mathrm{L}$ (Ittisa). Because phosphorus, as phosphates, is not deleterious to human health, guidelines like WHO and other national standards, do not typically list criteria for acceptable phosphorus concentrations for drinking water quality. The results of one-way ANOVA $(p=0.05)$ found that the $\mathrm{PO}_{4}^{3-}$ concentrations among the water springs varied considerably owing to the natural contact of these waters with $\mathrm{PO}_{4}{ }^{3-}$ minerals which could be affected by the $\mathrm{pH}$ and the temperature of the waters.

\section{CONCLUSIONS}

Safe water is a precondition for health and development. Therefore, it necessitates knowing the quality of water for drinking. In this study, five densely populated spring waters (Ittisa, Abba Moga, Kersa, Ele Gonda and Merfata) of Iddo Wara Wale local area, Kellem Wollega, Ethiopia were analyzed for seven physicochemical parameters (temperature, $\mathrm{pH}, \mathrm{EC}$, TDS, COD, alkalinity and total hardness), and eight major chemical parameters $\left(\mathrm{SO}_{4}{ }^{2-}, \mathrm{PO}_{4}{ }^{3-}, \mathrm{NO}_{3}{ }^{-}, \mathrm{Cl}^{-}, \mathrm{Ca}, \mathrm{Mg}, \mathrm{Na}\right.$, and $\mathrm{K}$ ). During the study temperature, $\mathrm{pH}$ and $\mathrm{EC}$ were measured at site of sample collection. The COD, alkalinity, total hardness, $\mathrm{SO}_{4}{ }^{2-}, \mathrm{Cl}^{-}, \mathrm{Ca}$ and $\mathrm{Mg}$ were determined by titrimetric methods of analysis in laboratory. $\mathrm{PO}_{4}{ }^{3-}, \mathrm{NO}_{3}{ }^{-}$, TDS, $\mathrm{Na}$, and $\mathrm{K}$ were determined
Sci. Technol. Arts Res. J., April-June 2014, 3(2): 103-112

by instrumental methods of analysis in laboratory. All the analysis was carried out according to the procedures given in the standard methods. The obtained results of all the parameters were compared among the water springs. One-way ANOVA test $(P=0.05)$ showed that all physicochemical and major chemical parameters varied significantly between the studied water springs. The variation of determined parameters among the studied water springs are most probably from natural sources. The current study results were compared with $\mathrm{WHO}$ and Ethiopian guidelines for drinking water quality, and all analyzed parameters were below the established guideline values. Therefore, no health and aesthetic problems concerning with the analyzed parameters of the waters for drinking. Generally, the importance of the quality of water for human consumption (regarding both health and aesthetic based quality) makes it necessary to investigate and keep up to norms, including limits for all the parameters that directly affect human health and deteriorate water quality.

\section{REFERENCES}

Alley, E.R. (2007). Water Quality Control Handbook (2 ${ }^{\text {nd }}$ ed.). New York, United States of America: The McGraw-Hill Companies, Inc.

American Public Health Association, APHA. (1999). Standard Methods for the Examination of Water and Wastewater $\left(20^{\text {th }}\right.$ ed.). Washington, D.C., United States of America: American Public Health Association, American Water Works Association and Water Environment Federation.

Federal Democratic Republic of Ethiopia. (2011). National Drinking Water Quality Monitoring and Surveillance Strategy. Addis Ababa, Ethiopia: The Federal Democratic Republic of Ethiopia, Ministry of Health.

Gebrekidan, M. and Samuel, Z. (2011). Concentration of Heavy Metals in Drinking Water from Urban Areas of the Tigray Region, Northern Ethiopia. College of Natural and Computational Sciences, Mekelle University 3(1): 105121.

Lawson, E. (2011). Physico-Chemical Parameters and Heavy Metal Contents of Water from the Mangrove Swamps of Lagos Lagoon, Lagos, Nigeria. Advances in Biological Research, International Digital Organization for Scientific Information Publications 5(1): 08-21.

Maiti, S.K. (2004). Handbook of Methods in Environmental Studies: Water and Wastewater Analysis ( $2^{\text {nd }}$ ed. Vol. 1). Jaipur, India: ABD Publishers.

McMurry, J., and Fay, R. (2004). Hydrogen, Oxygen and Water. In: McMurry Fay Chemistry, K.P. Hamann $\left(4^{\text {th }}\right.$ ed.). New Jersey, United States of America: Pearson Education.

Miller, J.N., and Miller, J.C. (2010). Statistics and Chemometrics for Analytical Chemistry ( $6^{\text {th }}$ ed.). Harlow, England: Pearson Education Limited.

Ministry of water resources. (2008). Butajira - Ziway Areas Development Study on Water Quality. Addis Ababa, Ethiopia: Ministry of water resources, Water technology centre.

Namiesnik, J. and Szefer, P. (2010). Analytical measurements in aquatic environments. Boca Raton, United States of America: Taylor and Francis Group, LLC.

Onwughara, N.I., Ajiwe, V.I.E., and Nnabuenyi, H.O. (2013). Physicochemical Studies of Water from Selected Boreholes in Umuahia North Local Government Area, in 


\section{Habtamu Abdisa and Alemayehu Abebaw}

Abia State, Nigeria. International Journal of Pure and Applied Bioscience 1(3): 34-44.

Pakistan Environmental Protection Agency. (2008). National Standards for Drinking Water Quality. Islamabad: Ministry of Environment, Government of Pakistan.

Saadeh, M., Semerjian, L., and Amacha, N. (2012). Physicochemical Evaluation of the Upper Litani River Watershed, Lebanon. The Scientific World Journal, 462467: 1-8.

Skoog, D.A., West, D.M., Holler, F.J., and Crouch, S.R. (2014). Fundamentals of Analytical Chemistry ( $9^{\text {th }}$ ed.). Belmont, United States of America: Brooks/Cole, Cengage Learning.

Tebbutt, T. H. Y. (1998). Principles of Water Quality Control $\left(5^{\text {th }}\right.$ ed.). Linacre House, Jordan Hill, Oxford: ButterworthHeinemann.

United Nations Environment Programme, UNEP. (2004). Analytical Methods for Environmental Water Quality. United Nations Environment Programme Global Environment Monitoring System/Water Programme and International Atomic Energy Agency. Available on: http://www.Gemswater.org/quality assurance/indexe.html. Accessed on January 12, 2012.
Sci. Technol. Arts Res. J., April-June 2014, 3(2): 103-112

United States Environmental Protection Agency, USEPA. (2007). Environmental Monitoring Systems Laboratory. Cincinnati Ohio, United States of America: Office of Research and Development.

Weiner, E. R. (2008). Applications of Environmental Aquatic Chemistry: A Practical Guide $\left(2^{\text {nd }}\right.$ ed.). Boca Raton, United States of America: Taylor and Francis Group, LLC.

Wisconsin Department of Natural Resources (1996). Analytical Detection Limit Guidance and Laboratory Guide for Determining Method Detection Limits. Madison, United States of America: Wisconsin Department of Natural Resources, Laboratory Certification Program.

World Health Organization, WHO. (2007). Water for Pharmaceutical Use. In: Quality Assurance of Pharmaceuticals: A Compendium of Guidelines and Related Materials. Geneva, Switzerland: World Health Organization.

World Health Organization, WHO. (2011). Guidelines for Drinking-water Quality. Geneva, Switzerland: World Health Organization.

Zhang, C. C. (2007). Fundamentals of Environmental Sampling and Analysis. Hoboken, New Jersey, United States of America: John Wiley and Sons, Inc. 